\title{
Múltiplos olhares sobre o Museu
}

Gilmara Célia Lana Rodarte Lopes ${ }^{1}$

FIGUEIREDO, Betânia Gonçalves; VIDAL, Diana Gonçalves (Org.). Museus - dos gabinetes de curiosidades à museologia moderna. Belo Horizonte: Argumentum, 2005. $239 \mathrm{p}$.

Museus - dos gabinetes de curiosidades à museologia moderna traz enorme contribuição às linhas de pesquisa que perpassam, de algum modo, a questão dos museus. A coletânea de artigos organizada pelas pesquisadoras Betânia G. Figueiredo e Diana G. Vidal abarca uma série de olhares sobre o museu, seja enfocando os aspectos históricos que caracterizaram e, ainda hoje, caracterizam sua constituição; seja destacando os aspectos da cultura material que cercam a museologia; ou ainda abordando os desafios educativos que, de maneira substancial, envolvem a aproximação com o público visitante. Dessa forma, a obra foi dividida em três partes que organizam os aspectos mencionados em relação ao objeto Museu.

O último espaço do livro foi dedicado ao tema "Museus e educação", requerendo a atenção dos educadores. Constata-se que a educação é um tema recorrente e pertinente tratando-se de museus e que, cada vez mais, procura-se compreender de que maneira esses espaços contribuem para a educação dos visitantes e para a produção do conhecimento. Nesse sentido, os quatro artigos abordam questões distintas, sendo estas verificadas pelos títulos dos mesmos: "Museus de ciências como espaços de educação" (M. Marandino), "Inventariando a escola do futuro revisitando o passado" (M. L. Felgueiras), "A imagem como fonte na pesquisa em História da Educação" (A. M. C. Peixoto) e "O desafio de construção de uma nova prática educativa para os museus" (S. S. Nascimento). O texto de Marandino abre a discussão sobre a educação considerando aspectos peculiares dos museus de ciências enquanto espaços educativos. A autora inicia seu texto com uma série de questões desencadeadas em função de uma única pergunta: serão os museus ambientes de educação? Marandino parte do pressuposto de que os museus de ciências são espaços

1 Professora da rede estadual de ensino de Minas Gerais (Belo Horizonte/Brasil). gilmara_lopes@yahoo.com.br. 
educacionais, e passa discorrer sobre questões que de alguma maneira interferem no processo educativo dentro dos museus, o que ela denomina "Pedagogia Museal": a exposição, o discurso, a interatividade, os objetos, os monitores, a mediação. Ao final, propõe um modelo para o estudo das relações pedagógicas nos museus de ciências, com a finalidade de ajudar na compreensão dos processos educacionais que neles acontecem, e ainda defende a idéia de que a exposição nos museus de ciências deve procurar aproximar "O saber sábio dos saberes dos diferentes públicos que visitam esses espaços” (p. 174, grifo da autora) para facilitar os processos educativos. Trata-se de um texto curto e denso, que talvez pudesse ser melhor compreendido se trabalhado em um artigo mais extenso e que permitisse à autora discorrer detalhadamente sobre suas idéias. Acreditase que desse modo a compreensão dos vários aspectos discutidos em relação aos museus de ciências seria facilitada.

O texto de Felgueiras aborda a questão do inventariado e da memória, outros dois aspectos fundamentais quando se trata de museus. $\mathrm{O}$ autor discute esses fatores no processo de criação de um museu da escola em Portugal e também a maneira pela qual a compreensão desses fatores pode interferir no entendimento da instituição escolar, defendendo a idéia de que o entendimento dos aspectos históricos escolares é fundamental para a compreensão do presente e do futuro escolar. Aborda a cultura material escolar, a diferença entre conhecimento, informação e comunicação e a caracterização da exposição do museu da escola como elementos que ajudam na valorização do patrimônio escolar.

$\mathrm{O}$ artigo de Peixoto analisa as imagens como fonte de pesquisa da História da Educação e argumenta que a imagem não se esgota em si mesma, havendo sempre muito mais a ser apreendido do que nela é lido ou observado. A autora busca junto ao Museu da Escola de Minas Gerais a coleção de livros e manuais escolares para estudar as imagens e procurar elucidar aspectos importantes da educação, especialmente relacionados à ideologia, às mentalidades e ao cotidiano escolar. Dessa forma, Peixoto analisa o acervo e verifica uma predominância de livros de leitura e de cartilhas, que constitui um indicativo da importância da leitura e da escrita no processo de escolarização brasileira.

O último artigo dessa parte, elaborado por Nascimento, fornece elementos bastante pertinentes para o entendimento dos museus enquanto espaços educativos e discute os desafios de se construir práticas educativas consistentes para esses espaços. Nesse sentido, o autor questiona e dialoga 
com a expografia e com os novos olhares que se lançam sobre o espaço museal. A seu ver, nos dias de hoje, há a necessidade de se elaborar formas museográficas que abarquem todos os sentidos do museu: um lugar de preservação do patrimônio e de coleções de objetos e artefatos da cultura material e imaterial, mas também local de lazer, prazer, sedução, encantamento, reflexão e busca de conhecimento. Em seguida, faz um percurso histórico sobre as práticas educativas nos museus e aborda a questão da interatividade como um aspecto atual dentro dos espaços museais e como o diálogo entre elementos fundamentais da exposição: os objetos, os visitantes, as informações, os monitores e a própria prática educativa. Por último, traz um exemplo de uma nova prática educativa desenvolvida no Museu Histórico Abílio Barreto, em Belo Horizonte, e mostra a necessidade de se constituírem formas museográficas que dialoguem com o visitante com o intuito de produzir novos espaços de aprendizagem.

A primeira parte do livro é intitulada "Museus e cultura material" e traz dois artigos - "A exposição museológica e o conhecimento histórico" (U. T. B. Meneses) e "Cultura material e coleção em museus de história: as formas espontâneas de transferência do povoado" (S. F. Lima e V. C. Carvalho). O texto de Meneses fornece, de maneira crítica, um excelente panorama sobre pontos fundamentais relacionados aos museus, como acervo, tipologia, objeto museal, documento histórico e exposição museológica, mas os museus históricos recebem destaque por serem objetos de pesquisa de seu estudo. É um artigo que merece destaque na obra e permite uma reflexão mais profunda sobre a relação entre a produção do conhecimento histórico e os museus históricos.

O texto de Lima e Carvalho traz para discussão a coleção, sendo esse um tema pertinente ao se considerar que a cultura material ainda é um dos temas fundamentais dentro dos museus, ainda que, na atualidade, a cultura imaterial e os museus sem acervo sejam possíveis de ser concebidos. Os artefatos culturais constituem-se como instrumento de trabalho nos museus, e é abordando uma perspectiva de como as coleções tornam-se objetos museais e de como a sociedade busca os museus para tornarem públicas suas coleções particulares que as autoras produzem o artigo. Dessa maneira, as autoras trazem à tona fatores interessantes sobre o colecionismo, afirmando que esse é um tema estratégico quando se trata de entender aspectos da reprodução das relações sociais e, ao analisar doações feitas ao museu, pretendem demonstrar o significado social do 
ato de doar. De acordo com Lima e Carvalho, "fazer uma oferta ao museu é uma forma de apropriação física do espaço público e de resignificação dos sentidos que esta instituição propaga (...)"(p. 88). Isso fica claro nos exemplos elucidativos que as autoras trazem dessa imagem que a sociedade faz dos museus, de suas coleções particulares e de como a doação é observada como um modo de homenagear e/ou transferir para a dimensão pública da vida social vestígios muito particulares da vida privada.

A segunda parte da coletânea - "Museus e sua história" - abarca três artigos: "A era dos 'Museus de etnografia' no Brasil: o Museu Paulista, o Museu Nacional e o Museu Paraense em finais do XIX” (L. K. M. Schwarcz), "Cultura, ciência e política: olhares sobre a história da criação dos museus no Brasil" (A. M. A. Machado) e "Classificar e ordenar: os gabinetes de curiosidades e a história natural" (H. C. G. Possas). Destacase o texto de Schwarcz, por trazer elementos históricos da criação e organização desses espaços no Brasil, e o texto de Possas, que aborda as mudanças ocorridas na história e a maneira pela qual permitiram que os gabinetes de curiosidades se tornassem os museus em sua concepção atual, destacando os aspectos de legitimação desses espaços. $\mathrm{O}$ artigo de Machado complementa o de Schwarcz, ao discutir "como o Estado agiu para estabelecer uma política voltada para os museus brasileiros, através de seus ideólogos e suas aspirações culturais"(p. 137). Dessa forma, essa parte do livro traz artigos que discutem aspectos da história dos museus brasileiros e permitem uma melhor compreensão da atualidade.

Com esse panorama, percebem-se as reais contribuições da obra para as áreas do conhecimento que dialogam com o objeto Museu em suas mais diversas situações. O leitor interessado no tema vai encontrar um livro com referências bibliográficas de qualidade, que o ajudarão a aprofundar seus conhecimentos sobre o tema Museu.

Museus - dos gabinetes de curiosidades à museologia moderna, além de ser uma obra de interesse de todos que tem os museus como objeto de estudo e lançam sobre eles múltiplos olhares, é também um agradável convite ao olhar dos não iniciados no assunto.

Recebido em: 06/11/2006

Aprovado em: 21/11/2006 